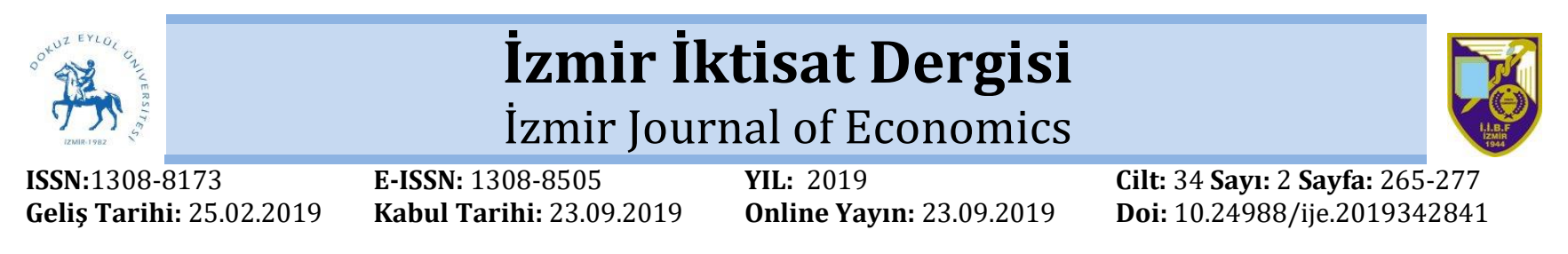

\title{
OECD Ülkelerinde Demokratikleşme ve Vergi Gelirleri İlişkisi: Bootstrap Panel Nedensellik Analizi \\ Mahmut Ünsal ŞAŞMAZ1
}

\begin{abstract}
Özet
Demokratikleşme, bir ülkenin gelişmişliği ile yakından ilişsili bir olgudur. Demokratikleşmeye bağlı olarak ülke içinde güven ve istikrar durumu ile birlikte artan yatırımlar sonucunda milli gelirde artış yaşanabilmektedir. Artan milli gelir ile birlikte üretim ve tüketim faaliyetlerinde belirgin artış oluşmakta ve kamunun en önemli gelir kaynağı olan vergiler üzerinde de etkilere neden olabilmektedir. Bu nedenle demokratikleşme ve vergi gelirleri ilişkisini incelemek önemli olmaktadır. Bu çalışmada, bootstrap panel nedensellik analizi yöntemi kullanılarak 32 OECD ülkesi için 2010-2017 döneminde demokratikleşme ile vergi gelirleri ilişkisi incelenmiştir. Yapılan çalışma sonucunda; 6 ülkede demokratikleşmeden vergi gelirlerine doğru, 5 ülkede ise vergi gelirlerinden demokratikleşmeye doğru nedensellik ilişkisi olduğu sonucuna ulaşılmıștır. Ayrıca ülkeler içerisinde sadece Estonya'da demokratikleşme ile vergi gelirleri arasında çift yönlü nedensellik ilişkisi tespit edilmiştir.
\end{abstract}

Anahtar kelimeler: Demokratikleşme, Vergi geliri, Bootsrap Panel Nedensellik testi Jel Kodu: H2, C23

\section{The Relationship between Democratization and Tax Revenues in OECD Countries: Bootstrap Panel Causality Analysis}

Abstract

Democratization is closely related to the development of a country. Depending on the democratization, an increase in national income may occur as a result of increasing investments and confidence in the country. Along with the increase in national income, it may have a significant impact on production and consumption activities as well as on taxes which are the most important source of income of the people. Therefore, it is important to examine the relationship between democratization and tax revenues. In this study, the relationship between democratization and tax revenues is examined for 32 OECD countries using bootstrap panel causality analysis method in 2010-2017 period. As a result of the study; from democratization to tax revenues in 6 countries, in 5 countries, it is concluded that there is a causal relationship between tax revenues to democratization. In addition, the two-way causality relationship between democratization and tax revenues has been determined in Estonia.

Keywords: Democratization, Tax Income, Bootstrap Panel Causality test

Jel Codes: H2, C23

\section{GİRIŞ}

Demokrasi, ülke yönetiminde halkın yönetime katılması olarak ifade edilebilir. Genel itibariyle demokrasi düzeyine bağlı olarak ülkelerin gelişme düzeyinin de paralel seyrettiği görülmektedir. Demokrasi endeksi 2017 verilerine göre, çalışmada kullanılan 32 OECD ülkesinden ilk dört sırada Norveç, İzlanda, Danimarka, İsveç olduğu görülmekte (EIU, 2018) ve İnsani Gelişme Endeksi (İGE) göz önünde bulundurulduğunda, bu ülkeler gelişmiş ülkeler olmakla birlikte sosyal refah devletleri olarak da bilinmektedir.

Ülkelerin demokratikleşme seviyesine bağlı olarak gelişme seviyesi artabilmekte ve bunun sonucunda ülkelerde sosyal, toplumsal, ekonomik, siyasi, kültürel gibi birçok gelişme yaşanabilmektedir. Alakbarov ve Bayar (2018) tarafından da ortaya koyulduğu gibi, demokrasi ekonomik büyümeyi özellikle ülkelerin belli bir demokrasi eşik seviyesine ulaştıktan sonra etkilemektedir. Bunun yanı sıra, demokrasinin ülkedeki kurumsal, eğitimsel ve altyapı

\footnotetext{
${ }^{1}$ Dr. Öğr. Üyesi, Uşak Üniversitesi, İktisadi ve İdari Bilimler Fakültesi, Maliye Bölümü Uşak, mahmut.sasmaz@usak.edu.tr ORCID: 0000-0001-9485-3933
} 
özellikleri gibi ülkeye özgü faktörlere bağlı olarak uzun vadede ekonomik büyüme üzerinde farklı etkileri olmaktadır. $\mathrm{Bu}$ bağlamda ifade edecek olursak, demokrasi düzeyine bağlı olarak her alanda olduğu gibi ekonomi alanında da gelişmeler yaşanması ile birlikte vergi gelirlerinde de belli değişimler yaşanabilmektedir.

Demokratikleşme ile birlikte güven ve istikrar ortamı sonucunda yatırım faaliyetleri artış göstermekte ve bunun sonucunda da milli gelir iyileşmektedir. Milli gelirde yaşanan iyileşme ile birlikte üretim ve tüketim faaliyetlerinde artışlar yaşanabilmektedir. Üretim ve tüketim faaliyetlerinin artması sonucunda devletin en önemli kaynağı olan vergi gelirlerinde de değişiklikler meydana gelmektedir. Ayrıca ekonomi politikalarında siyasi rejim ve kurumların etkili olmasına bağlı olarak vergi politikaları da bu kurumlar sonucunda belirlenmektedir. Bu nedenle demokratikleșme ile vergi gelirleri ilişkisini araştırmak önem arz etmektedir.

Bu çalışmada konunun daha iyi anlaşılabilmesi amacıyla öncelikle demokratikleşme ve vergi gelirleri ile ilgili teorik bilgilere yer verilmiștir. Daha sonra bu konuda yapılan ampirik çalışmalar özetlenmiştir. Ardından çalışmada kullanılan ekonometrik yöntemler ve ampirik sonuçlara yer verilmiş ve çalışma değerlendirme ve öneriler ile sonlandırılmıştır.

\section{TEORI}

Hem demokratik yönetimde hem de otoriter yönetimde bir ülkedeki siyasal sistem, devletin verdiği tüm politika kararlarında ve bu kararları uygulamak için kullandığı yöntemlerde önemli rol oynar. $\mathrm{Bu}$ sebeple, genel anlamiyla maliye politikalarının yürürlükteki siyasal sistemden etkilenmesi normaldir (Balamatsias, 2016: 2). Vergilendirme ve kamu harcamaları ekonomi ve politikadaki temel konulardır. Vergi tasarımı ve reformlarının uygulanması ile devlet harcama programları ekonomik politikanın temelini oluşturmaktadır. Demokrasilerde, vergilendirme ve kamu harcamaları, özellikle ideolojik olmayan vatandaşların (muhtemelen seçmenlerin büyük bir kısmı olan) oylarını çekebilir ve değiştirebilir (Profeta vd., 2013: 2).

Vergiler son iki yüzyıl boyunca seviye ve hacim bakımından artarken vergilerin yapıları da değișime uğramıștır. On dokuzuncu yüzyılın başlarında gümrük vergilerine bağımlılık varken, yirminci yüzyılda gelir vergileri yoğunluk kazanmıştır. Bu gelişmelerin nedeni olarak ortak kanı, yeniden dağıtım ile hükümet boyutunu arttıran demokrasinin yaygınlaşması olduğu yönündedir (Anderson, 2018: 111). Vergilendirme, gelirin veya kaynakların vatandaşlardan devlete aktarılmasıdır. Bu nedenle hem vergi gelirlerinin düzeyi ve bileşimi hem de vergi kaynakları ve bu kaynaklardan vergi almak ile kullanılan yöntemler siyasal sistemden etkilenmektedir (Balamatsias, 2016: 2). Vergi ile bireyler, kural koyucuların üzerinde denetim hakkıyla pazarlık gücünü elde etmektedir. Vergi demokrasi talebini oluştururken, demokratik ilerleme de vergi toplama etkinliği ile meşruiyetini arttırmaktadır (Türedi ve Topal, 2016: 64).

Bates ve Lien (1985), Acemoğlu ve Robinson $(2000,2005)$ tarafindan yapılan araştırma sonuçlarına göre, vergi ve demokrasi arasında karşılıklı nedensellik ilişkisi söz konusudur.

Bates ve Lien (1985), Fransa ve İngiltere gibi Batı Avrupa ülkelerinin tecrübelerine dayanarak, gelir arayan hükümetlerin vergi mükellefleriyle pazarlık etmenin nasıl bir sonuç verdiğini ve bunun demokratik hükümetlere nasıl yol açtığını incelemektedir. Yazarlara göre hem hükümetler hem de vergi ödeyenler fayda fonksiyonunu en üst düzeye çıarmak amacındadırlar. Yazarlar rasyonel davranan bir hükümetin faydasını en üst düzeye çıkarması ve dolayısıyla daha fazla fon toplaması için vergi mükelleflerine politika imtiyazları sunması gerektiği sonucuna varmaktadırlar. $\mathrm{Bu}$ imtiyazlar, vergi mükelleflerinin hükümet tercihlerini daha fazla kontrol etmesi şeklindedir. $\mathrm{Bu}$ nedenle, bu süreç vergilendirmenin artmasının vatandaşların daha demokratik bir șekilde temsil edilmesine yol açmasına sebep olmaktadır. 
Acemoğlu ve Robinson (2000, 2005)'e göre, eşitlikçi ve müreffeh ülkeler rejim değişikliği yaşamıyor, çünkü insanlar şartlardan memnunlar. Baskıcı ve son derece eşitsiz toplumlar da değişimler yaşamıyor, çünkü bu ülkelerdeki seçkinler konumlarını korumak için mümkün olan her türlü aracı kullanıyorlar.
Sonuç olarak, yüksek eșitsizliğe maruz kalan ülkelerde, ancak seçkinlerin, toplumsal huzursuzluk durumunda nüfusun çoğunluğunu cezalandırma gücüne sahip olmadığı ülkelerde, tam çoğunluğun lehine vergilendirmeyi artıran tam demokrasiye geçişler görülmektedir.

Tablo 1: 32 OECD Ülkelerinde Demokrasi Endeksi ve Vergi Gelirlerinin GSYH'ye Oranının Seyri (2010-2017 Dönemi)

\begin{tabular}{|c|c|c|c|c|c|c|c|}
\hline \multicolumn{4}{|c|}{ Demokratikleșme Endeksi } & \multicolumn{4}{|c|}{ Vergi Gelirleri (GSYH'nın \%’si) } \\
\hline Ülkeler & 2010 & Ülkeler & 2017 & Ülkeler & 2010 & Ülkeler & 2017 \\
\hline Norveç & 9,80 & Norveç & 9,87 & Danimarka & 44,76 & Fransa & 46,23 \\
\hline İzlanda & 9,65 & İzlanda & 9,58 & İsveç & 43,22 & Danimarka & 45,98 \\
\hline Danimarka & 9,52 & İsveç & 9,39 & Belçika & 42,62 & Belçika & 44,6 \\
\hline İsveç & 9,50 & Danimarka & 9,22 & Fransa & 42,15 & İsveç & 43,96 \\
\hline Finlandiya & 9,19 & Kanada & 9,15 & Norveç & 41,9 & Finlandiya & 43,34 \\
\hline Kanada & 9,08 & İrlanda & 9,15 & İtalya & 41,86 & İtalya & 42,38 \\
\hline Hollanda & 8,99 & Finlandiya & 9,03 & Avusturya & 40,96 & Avusturya & 41,77 \\
\hline Lüksemburg & 8,88 & Hollanda & 8,89 & Finlandiya & 40,79 & Yunanistan & 39,39 \\
\hline İlanda & 8,79 & Lüksemburg & 8,81 & Lüksemburg & 37,4 & Hollanda & 38,75 \\
\hline Avusturya & 8,49 & Almanya & 8,61 & Macaristan & 37,27 & Lüksemburg & 38,65 \\
\hline Almanya & 8,38 & İngiltere & 8,53 & Slovenya & 36,9 & Norveç & 38,23 \\
\hline Çekya & 8,19 & Avusturya & 8,42 & Hollanda & 35,66 & Macaristan & 37,71 \\
\hline Amerika & 8,18 & İspanya & 8,08 & Almanya & 35,01 & İzlanda & 37,69 \\
\hline İngiltere & 8,16 & Güney Kore & 8,00 & Estonya & 33,25 & Almanya & 37,54 \\
\hline İspanya & 8,16 & İtalya & 7,98 & İzlanda & 33,2 & Slovenya & 36,02 \\
\hline Güney Kore & 8,11 & Amerika & 7,98 & Çekya & 32,48 & Çekya & 34,89 \\
\hline Belçika & 8,05 & Şili & 7,84 & İngiltere & 32,31 & Portekiz & 34,71 \\
\hline Portekiz & 8,02 & Portekiz & 7,84 & Yunanistan & 32,02 & Polonya & 33,9 \\
\hline Yunanistan & 7,92 & Fransa & 7,80 & Polonya & 31,41 & İspanya & 33,66 \\
\hline İtalya & 7,83 & Estonya & 7,79 & İspanya & 31,21 & İngiltere & 33,26 \\
\hline Fransa & 7,77 & İsrail & 7,79 & Kanada & 31,08 & Estonya & 32,97 \\
\hline Slovenya & 7,69 & Belçika & 7,78 & İsrail & 30,75 & Slovakya & 32,9 \\
\hline Estonya & 7,68 & Çekya & 7,62 & Portekiz & 30,41 & İsrail & 32,73 \\
\hline Şili & 7,67 & Slovenya & 7,50 & Litvanya & 28,29 & Kanada & 32,24 \\
\hline İsrail & 7,48 & Litvanya & 7,41 & Letonya & 28,22 & Letonya & 30,4 \\
\hline Slovakya & 7,35 & Yunanistan & 7,29 & Slovakya & 28,07 & Litvanya & 29,84 \\
\hline Litvanya & 7,24 & Letonya & 7,25 & İrlanda & 27,01 & Amerika & 27,14 \\
\hline Macaristan & 7,21 & Slovakya & 7,16 & Türkiye & 24,82 & Güney Kore & 26,9 \\
\hline Letonya & 7,05 & Polonya & 6,67 & Amerika & 23,49 & Türkiye & 24,89 \\
\hline Polonya & 7,05 & Macaristan & 6,64 & Güney Kore & 23,39 & İrlanda & 22,84 \\
\hline Meksika & 6,93 & Meksika & 6,41 & SSili & 19,59 & SSili & 20,16 \\
\hline Türkiye & 5,73 & Türkiye & 4,88 & Meksika & 12,84 & Meksika & 16,17 \\
\hline
\end{tabular}

Kaynak: Demokrasi endeksi EIU (2018)'den, vergi gelirleri OECD (2019)'dan alınmıştır.

Kenny ve Winer (2006) siyasi rejimin vergilendirme sonuçlarındaki rolünü araştırırken, demokratik olmayan rejimlerin doğrudan vergilendirme gibi vatandaşlardan daha fazla uyum gerektiren vergilerden uzaklaştığını gösterirken, daha demokratik hükümetler ilerici niteliklerinden dolayı doğrudan vergileri daha fazla kullanmaktadır. Ayrıca, bu tür vergiler, bir demokraside elde 
edilmesi daha kolay olan vergi mükelleflerinden işbirliği gerektirmektedir.

Çalışmada kullanılan ve The Economist Intelligence Unit (EIU) tarafindan hesaplanan demokrasi endeksi, demokrasi devletinin bir görüntüsünü sağlar ve dünya çapında 165 bağımsız devlet ve iki bölgeden oluşmaktadır. Endeks 0-10 arasında değer almakta ve beş kategoriye ayrılmış 60 göstergenin derecelendirmesine dayanmaktadır. $\mathrm{Bu}$ beș kategori; seçim süreci ve çoğulculuk, sivil özgürlükler, hükümetin işleyişi, siyasi katılım ve siyasi kültürden oluşmaktadır. Puanlamaya dayalı olarak ülkeler "tam demokrasi", "kusurlu demokrasi", "hibrit rejim" ve "otoriter rejim" olmak üzere dört kategoriye ayrılmaktadır (EIU, 2018). Endeks değeri 0'a yaklaştıkça demokratikleşme düzeyi düşmekte, 10'a yaklaştıkça demokratikleşme düzeyi artmaktadır.

Tablo 1'de 32 OECD ülkesinde demokrasi endeksi ve vergi gelirlerinin GSYH' ya oranının yıllara göre seyri (2010-2017 dönemi) verilmiştir. Tablo'da ülke sıralaması demokrasi endeksi ve vergi gelirlerinin GSYH'daki payı büyükten küçüğe doğru verilmiştir. Böylelikle ülkelerin demokrasi düzeyi ile vergi gelirleri arasındaki ilişki daha net bir şekilde ortaya çıkmaktadır. Nitekim tablo'da da demokrasi düzeyi düşük olan ülkelerin GSYH'daki vergi payının daha düşük olduğu göze çarpmaktadır. 2010 yılında demokrasi endeksinin en yüksek olduğu ülke Norveç olurken, en düşük demokrasi endeksine sahip ülke Türkiye olmuştur. 2017 yılı verilerine bakıldığında, en yüksek ve en düşük demokrasi endeksine sahip olan ülkelerin değişmediği görülmektedir. 2010 yılı vergi gelirlerinin GSYH'ye oranına bakıldığında en yüksek oran Danimarka'da iken en düșük oran Meksika'da görülmektedir. 2017 yılına gelindiğinde en yüksek oran Fransa'da olurken en düşük oran Meksika'da gerçekleşmiştir.

Demokrasi endeksinin ülkenin demokrasi anlamında gelişmişliğine göre değişiklik gösterebileceği ifade edilebilir. Vergi gelirlerinin GSYH' ye oranının ülkeden ülkeye değișiklik göstermesinin sebebi; vergi oranları, vergi yükü, vergi idaresi ve vergi denetimine bağlı olabileceği gibi ülkenin gelişmişlik düzeyine bağlı olarak kişi bașına düşen gelir de olabilir.

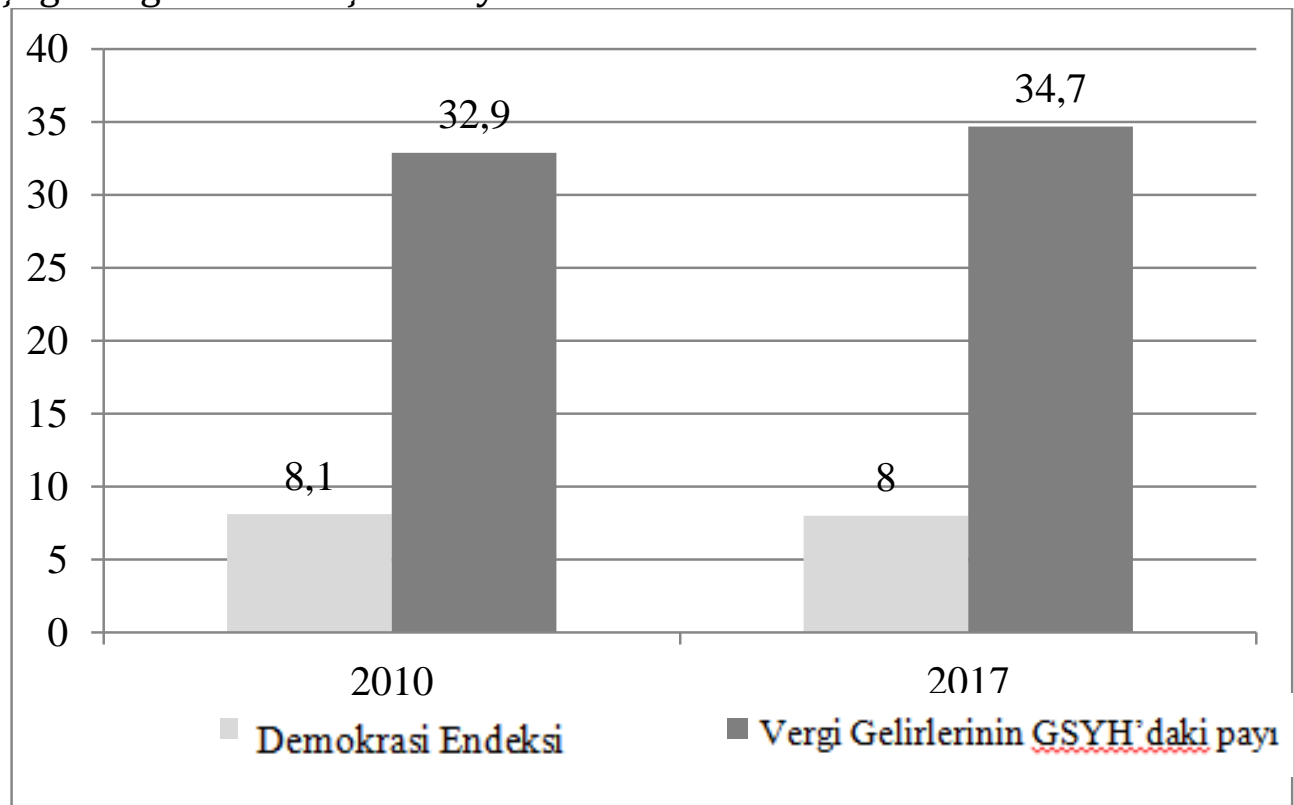

Şekil 1: 32 OECD Ülkesinde 2010-2017 Döneminde Demokrasi Endeksi ve Vergi Gelirlerinin GSYH'ya Oranının Seyri

Kaynak: Demokrasi endeksi EIU (2018)'den, vergi gelirleri OECD (2019)'dan alınmıştır. Ortalama tarafımızdan hesaplanmış ve grafiğe aktarılmıștır. 
Şekil 1'de 32 OECD ülkesinde demokrasi endeksi ile vergi gelirlerinin GSYH'ya oranının 2010-2017 dönemi ortalama seyri verilmiștir. Grafiğe bakıldığında demokrasi endeksinin 2010 yılından 2017 yılına doğru 0,1 puan azalış gösterdiği; vergi gelirlerinin GSYH'ya oranının 2010 yılından 2017 yılına doğru \%1,8 artış gösterdiği görülmektedir.

\section{LİTERATÜR TARAMASI}

Demokrasi ile vergiler/vergi gelirleri arasındaki ilişskiye yönelik literatürde çeșitli ampirik çalışmalar bulunmaktadır (Bkz. Cheibub (1998), Torgler (2005), Ehrhart (2011), Mutascu (2011), Profeta vd. (2013), Ziari ve Rahemi (2013), Baskaran (2014), Balamatsias (2016), Kılıçer vd. (2016),Türedi ve Topal (2016), Andersson (2018)). Yapilan çalışmalarda ulaşılan sonuç genellikle demokrasi düzeyi ile vergi gelirleri arasındaki ilişkinin pozitif yönlü olduğu veya demokrasi ile vergiler arasında nedensellik ilişkisi olduğu yönündedir (Bkz. Ehrhart (2011), Mutascu (2011), Ziari ve Rahemi (2013), Balamatsias (2016), Türedi ve Topal (2016). Diğer yandan demokrasi ile vergi gelirleri arasındaki ilişkinin kır-kente göre vergi türünde değişiklik gösterebildiğini saptayan çalışmalar (Bkz. Andersson (2018)) veya demokrasi ile vergi gelirleri arasında önemli bir ilișki olmadığını belirleyen çalışmalar da mevcuttur (Bkz. Profeta vd. (2013)). Ayrıca literatürde demokrasi ve vergiler arasındaki ilişkiye yönelik veya bu konuya ilişkin yapılmış çeşitli anket çalışmaları da mevcuttur (Bkz. Zenginobuz vd. (2010), Şahin ve Hatırlı (2016)). Demokrasi ile vergi gelirleri arasındaki ilişkiye yönelik çalışmalardan bazıları aşağıda özetlenmiştir:

Yaptıkları çalışmada hükümet büyüklüğünü ele alan Meltzer ve Richard (1981)'e göre; seçmenler, vergilendirmenin vatandaşların emek-eğlence seçimleri üzerindeki ayırt edici etkilerini rasyonel olarak öngördüklerini ve oylama yaparken bunu dikkate aldıklarını belirtmişlerdir. Çalışmada yeniden dağıtılan gelir payıyla ölçülen hükümetin büyüklüğünün, çoğunluk kuralına göre belirlenmekte olduğunu belirtmișlerdir. Diğer bir çalıșmada Cheibub (1998), 1970 ile 1990 yılları arasında 108 ülkede demokrasi veya diktatörlük olarak sinıflandırılan rejim türü ile vergilendirme arasındaki ilişkiyi incelemiştir. Çalışma sonucuna göre, hükümet tarafından toplanan vergi seviyesine ilişkin ülkeler arasında gözlemlenen farklılıkların bazılarının demokrasi, altında olması ve diğerlerinin diktatörlük ile sınıflandırılmış olması nedeniyle demokratik rejimlerin vergi toplayamama endișelerinin asılsız olduğu belirtilmiştir. Benzer bir çalıșmada Pommerehne ve WeckHannemann (1996), 25 İsviçre Kantonunda vergi kaçakçlığının standart modeline uygun olarak toplam gelir vergisi uyumsuzluğunun ampirik araştırmasını yapmışlardır. Yapılan çalışma sonucunda ulaşılan sonuçlardan birinde, vatandaş / vergi mükelleflerinin devlet bütçeleri üzerinde doğrudan kontrolü olduğunda, uyumsuzluğun önemli ölçüde daha düşük olduğunu oysa böyle bir kontrolün olmadığı durumlarda bunun tam tersinin geçerli olduğunu tespit etmişlerdir.

Demokrasinin vergi gelirine etkisini araştıran Torgler (2005), İsviçre'de Uluslararası Sivil Toplum Araştırmaları Anketi (ISSP) 1998'den alınan anket verilerini kullanmıştır. Çalışmada, doğrudan demokratik hakların vergi ahlakını önemli ölçüde olumlu etkilediği belirlenmiştir. Ehrhart (2011) tarafından yapılan diğer bir çalışmada, panel veri analizi kullanılarak 19902005 döneminde 66 gelişmekte olan ülkede demokrasi ile vergi gelirleri arasındaki ilişki araştırılmıştır. Kullanılan değişkenler üç yıllık ortalamalardan oluşmaktadır. Yapılmış olan çalışma sonucunda, artan demokrasinin vergi gelirleri üzerindeki muhtemel etkisinin büyük olduğu sonucuna ulaşmıştır. Benzer bir çalışmada Mutascu (2011), panel veri analizi yöntemini kullanarak 51 ülkede 2002-2008 yılları arasında vergilendirme düzeyi ile demokrasi arasındaki ilişkiyi incelemiştir. Çalışmada, gerek güçlü bir demokratik yapının varlığında gerekse güçlü bir otoriter yönetimin varlığı halinde önemli bir vergi artışının meydana gelebileceği sonucuna ulaşılmıştır. Başka bir çalışmada Profeta vd. (2013), 
regresyon analizi yöntemini kullanarak belli gelişmekte olan ülkelerde 1990-2005 döneminde demokrasi, vergilendirme ve kamu harcamaları arasındaki ilişkiyi incelemişlerdir. Çalışma sonucuna göre, politik değişkenler ile vergi gelirleri arasında önemli bir ilișkinin olmadığı belirlenmiş̦tir. Benzer bir çalışmada Ziari ve Rahemi (2013), 21 ülkeye yönelik düşük, orta ve yüksek demokrasi endeksine sahip üç grupta 2006-2011 yılları arasında demokrasi endeksi ile vergi gelirleri arasındaki ilişkiyi araştırmışlardır. Ziari ve Rahemi (2013)'e göre, yüksek demokrasi endeksine sahip ülkelerde vergi gelirlerinin demokrasi endeksini olumlu yönde etkilediği tespit edilmiştir. Ortalama demokrasi endeksine sahip ülkelerde vergi gelirlerinin demokrasi endeksi üzerinde de olumlu etkileri olduğu tespit edilirken, vergi hariç diğer gelirlerin demokrasi endeksi üzerinde olumsuz etkisi olduğu belirtilmiştir. Düşük demokrasi endeksine sahip ülkelerde vergi gelirlerinin demokrasi üzerinde olumsuz etkisi olduğu sonucuna ulaşmışlardır.

Çalışmasında vergilendirme ile demokrasi ilişkisini araștıran Baskaran (2014), 19812008 yılları arasında 122 ülkeye yönelik panel regresyon analizini kullanmıștır. Yapılan çalışma sonucunda gelirlerin ortalama olarak demokrasi üzerinde küçük olumlu bir etki oluşturduğunu tespit etmiştir. Benzer bir çalışmada Balamatsias (2016), iki aşamalı en küçük kareler (2SLS) yöntemini kullanarak 1993-2012 döneminde 74 ülkede demokrasi ile vergilendirme arasındaki ilişkiyi incelemiştir. Çalışma sonucunda, demokrasinin doğrudan vergilendirmede ve aynı zamanda dolaylı vergileme oranı üzerinde olumlu yönde etkisi olduğu tespit edilmiştir. Diğer bir çalışmada Kılıçer vd. (2016), OECD ve Türkiye'de katalaksı kavramı kapsamında vergileme ile demokrasi arasındaki ilişkiyi karşılaştırmalı analiz ve korelasyon analiz yöntemini kullanarak incelemişlerdir. Çalışmada vergisini beyannameli şekilde ödeyenlerin toplam seçmene oranı ile demokrasi arasındaki (demokrasiyi temsilen ifade özgürlüğü ile hesap verilebilirlik, hukukun üstünlüğü, yolsuzluk, açılk bütçe ve yolsuzluğun kontrolü endeksleri kullanılmıştır) ilişki analiz edilmiştir. Yapılan çalışmaya göre, korelasyon analizi sonucunda demokrasi göstergelerinin tamamının, beyanname veren mükellef sayısının seçmen sayısına oranı arttıkça daha yüksek değere ulaştığını belirlemişlerdir. Ayrıca demokrasi değerleri ile dolaysız vergiler (beyannameli mükellefler) arasında pozitif bir ilişki tespit edilirken beyannameli mükellef sayısındaki artışın demokrasi skorlarını arttırdığını belirlenmiștir. Başka bir çalışmada Türedi ve Topal (2016), panel nedensellik analizi yöntemini kullanarak 60 gelişmekte olan ülkeye yönelik 2006-2012 döneminde vergilendirme ve demokrasi ilişkisini incelemişlerdir. Çalışmada demokrasiyi temsilen dört değişken (sivil özgürlükler ve siyasal haklar, EIU demokrasi endeksi ve Polity IV) kullanılmıștır. Çalışma sonucunda vergilendirme ve demokrasi arsında çift yönlü nedensellik ilişkisi tespit edilmiştir.

Çalışmasında vergi gelirlerinin belirleyicilerini araştıran Özmen (2016), 1996-2013 yılları arasında BRIC-T ülkelerini örneklem olarak kullanmıştır. Çalışmada yöntem olarak panel birim kök ve panel eşbütünleşme testi kullanılmıştır. Çalışmada ekonomik, mali, sosyal ve siyasi değişkenlerin toplam vergi gelirleri üzerinde önemli derecede belirleyici rol oynadığı belirlenmiștir. Ayrıca çalışmada kullanılan değişkenler arasında yer alan ekonomik özgürlükler ve ticari serbestleşmenin katsayısının istatistiki olarak anlamlı ve politik istikrarın katsayısının ise istatistiki olarak anlamlı olmadığı sonucuna ulaşılmıştır. Demokratikleşmenin vergi gelirleri üzerindeki etkisini inceleyen Andersson (2018), tanımlayıcı ve çok değişkenli analiz yöntemini kullanarak 31 ülkede 1800'den sonra (ya da bağımsızlık sonrası) 2012'ye kadar olan süreci kullanmıştır. Çalışma sonucuna göre, demokrasinin kırsal ülkelerdeki emlak vergilerini düşürdüğü, bunun yerine gelir vergisini artırdığı ve daha şehirleşmiş bölgelerde tüketim vergilerini düşürdüğü tespit edilmiştir. Diğer yandan ekonomik 
özgürlükler demokratikleşme açısından önem teşkil etmekte hatta ülkelerin demokrasi seviyeleri hakkında ipucu verebilmektedirler. Tekin vd. (2018) çoklu regresyon modelini kullanarak altı modelden oluşan (tüm ülkeler, gelişmiş ülkeler, gelişmekte olan ülkeler, $\mathrm{AB}$, G20 ve OECD ülkeleri) 63 ülkede 2002 yllı sonrasındaki veriler kullanarak ekonomik özgürlüğün vergi kaçakçllığı ile sosyal refah düzeyi üzerindeki etkisini araştırmışlardır. Tekin vd. (2018) tarafından yapılan çalışma sonucunda, gelişmiş, gelişmekte olan, AB ile OECD üyesi ve tüm ülkelerde ekonomik özgürlüğün vergi kaçakçllığı üzerinde negatif bir etki meydana getirdiği tespit edilmiştir. Ayrıca ekonomik özgürlüklerin sosyal refah devleti üzerinde pozitif bir etkiye neden olduğunu belirlemişlerdir.

Demokrasi ile vergiler arasındaki ilişkiye yönelik literatürde anket çalışmaları da mevcuttur. Zenginobuz vd. (2010), vergi, temsiliyet ve demokrasi üzerine Türkiye'deki vatandaşların algılarına yönelik anket çalışması yapmışlardır. Çalışmanın örneklemini Türkiye'deki 2400 vatandaş oluşturmakta olup zaman aralığı 18 Haziran 2009-23 Temmuz 2009 arasında gerçekleşen saha çalışmasını kapsamaktadır. Çalışma sonucunda, vatandaşlık ve demokrasi tanımları üzerine yöneltilen sorularda, vatandaşların ülke yönetiminde söz sahibi olma hakkıyla vergi ödemeyi birbirleri ile bağlantılı unsurlar olarak gördüklerini tespit etmişlerdir. Yapılan başka bir anket çalışmasında Şahin ve Hatırlı (2016), vergi uygulamaları ve vergi ahlakı ilişkisini incelemek amaciyla Trabzon, Giresun ve Gümüşhane İl Defterdarlıklarına bağlı ticari ya da serbest meslek kazancl elde eden mükelleflerin geliri ile sosyo-ekonomik özelliklerine yönelik Temmuz 2010 döneminde 400 anket yapılmıştır ve veriler Logit Modeli ile analiz edilmiştir. Çalışma sonucunda, vergi denetimi, kamu güvencesi, vergileme eşitliği,

132 ülke; Avusturya, Belçika, Kanada, Şili, Çekya, Danimarka, Estonya, Finlandiya, Fransa, Almanya, Yunanistan, Macaristan, İzlanda, İrlanda, İsrail, İtalya, Güney Kore, Letonya, Litvanya, Lüksemburg, Meksika, demokrasi algısıyla vergi etiği arasında pozitif bir ilişki bulunmuştur.

\section{VERİ VE YÖNTEM}

Çalışmada 2010-2017 yılları arasında 321 OECD ülkesinde demokratikleşme ile vergi gelirleri arasındaki nedensellik ilişkisi araştırılmıştır. Çalışmada 32 OECD ülkesi ile 2010-2017 döneminin seçilmesinin nedeni, verilerin 32 OECD ülkesi için 2010-2017 döneminde sürekli olmasıdır. Çalışmada değişkenlerin belirlenmesinde teorik ve ampirik literatür dikkate alınmıştır. Çalışmada kullanılan demokratikleșme endeksi EIU (The Economist Intelligence Unit) (2018)'den, vergi gelirleri verisi OECD (2019)'dan elde edilmiştir. Tablo 2'de çalışmada kullanılan değişkenler ve tanımlamalara yer verilmiştir;

Tablo 2: Değişkenler ve Tanımlamalar

\begin{tabular}{|l|c|c|}
\hline \multicolumn{1}{|c|}{ Değişken } & Sembol & Kaynak \\
\hline $\begin{array}{l}\text { Demokratikleşme } \\
\text { Endeksi }\end{array}$ & DE & EIU \\
(2018)
\end{tabular}

Çalışmada yöntem olarak Kónya (2006) panel bootstrap nedensellik testi yöntemi seçilmiştir. Öncelikle seriler arasında yatay kesit bağımlılığı ilişkisi olup olmadığı test edilmiş ardından serilerin homojenliğine bakılmıştır. Son olarak panel bootstrap nedensellik analizi ile değişkenler arasındaki nedensellik ilişkisi incelenmiştir. Çalışmada demokratikleşme ile vergi gelirleri arasındaki nedensellik ilişkisine bakılmıştır. Modelin denklemi aşağıda verilmiştir;

Model: $\mathrm{VG}_{\mathrm{it}}=\alpha_{\mathrm{it}}+{ }_{\beta 1} \mathrm{DE}_{\mathrm{it}}+\mathrm{u}_{\mathrm{it}}$
Hollanda, Norveç, Polonya, Portekiz, Slovakya, Slovenya, İspanya, İsveç, Türkiye, İngiltere ve Amerika'dan oluşmaktadır. 


\section{Ampirik Analiz}

$\mathrm{Bu}$ bölümde yatay kesit bağımlılı̆̆ı testi, homojenlik testi ve bootstrap panel nedensellik testi yer almaktadır. Öncelikle ekonometrik analizde kullanılan testler ile ilgili bilgi verilmiş daha sonra test sonuçları verilerek yorumlanmıştır.

\subsection{Yatay Kesit Bağımlılığı Testi}

Ekonometrik analizde değişkenler arasında yatay kesit bağımlılığının olması durumunda, bu ilişkinin sınanmaması analizde çıkan sonuçları önemli ölçüde etkilemektedir (Pesaran, 2004). Yatay kesit bağımlılığı testi uygulanırken zaman boyutunun kesit boyutundan büyük olması durumunda Breusch ve Pagan (1980) LM testi, zaman boyutu kesit boyutundan küçük olduğunda Pesaran (2004)
CDLM testi (Denklem 2), zaman boyutu kesit boyutuna eşit olduğunda ise Pesaran (2004) CDLM2 testi uygulanır. Ayrica Pesaran vd. (2008) heterojen bir panelde önayarlı bir LM testini sonlu örnek yaklaşımlarını kullanarak geliştirmişlerdir (Baltagi vd. 2012).

$C D_{l m}=\sqrt{\frac{1}{n(n-1)}} \sum_{i=1}^{n-1} \sum_{j=i+1}^{n}\left(T \breve{\rho}_{i j}^{2}=\pi r^{2}-1\right)$

Yatay kesit bağımlılığı testinin sıfır hipotezi "yatay kesit bağımlılığı yoktur" șeklinde iken alternatif hipotez "yatay kesit bağımlılığı vardır" şeklindedir.

Tablo 3'te yatay kesit bağımlılı̆̆ı testi sonuçları verilmiştir;

Tablo 3: Yatay Kesit Bağımlılığı Test Sonuçları

\begin{tabular}{|l|c|c|c|c|}
\hline \multirow{2}{*}{\multicolumn{1}{c|}{ Test }} & \multicolumn{2}{c|}{ Demokratikleşme (DE) } & \multicolumn{2}{c|}{ Vergi Gelirleri (VG) } \\
\cline { 2 - 5 } & İstatistik & Olasılık & İstatistik & Olasılık \\
\hline Breusch-Pagan LM & 1699.091 & 0.000 & 1649.976 & 0.000 \\
\hline Pesaranscaled LM & 32.96161 & 0.000 & 31.49534 & 0.000 \\
\hline Bias-correctedscaled LM & 30.53304 & 0.000 & 29.06677 & 0.000 \\
\hline Pesaran CD & 2.040438 & 0.041 & 19.84132 & 0.000 \\
\hline
\end{tabular}

Yatay kesit bağımlılığı test sonuçlarında olasılık değeri 0,05'in altında olduğu zaman H0 hipotezi $\% 5$ anlamlılı düzeyinde reddedilmekte ve seriler arasında yatay kesit bağımlılığı olduğu sonucuna ulaşılmaktadır (Pesaran vd., 2008). Tablo 3'teki test sonuçlarına bakıldığında, panel genelinde seriler arasında yatay kesit bağımlılığı olduğu belirlenmiştir. Yatay kesit bağımlılığı tespit edildiğinden dolayı çalışmada yatay kesit bağımlılığının varlığını dikkate alan test tekniği tercih edilmiştir.

\subsection{Homojenlik Testi}

Çalışmada değişkenlerin eğim katsayılarının homojen olup olmadıklarını sınamak amaciyla Pesaran ve Yamagata (2008) homojenlik testi kullanılmıştır. Homojenlik testinin sıfır hipotezi eğim katsayılarının homojen olduklarını, alternatif hipotez ise eğim katsayılarının heterojen olduklarını ifade etmektedir. Test sonucunda elde edilen olasılık değerinin 0,10 'dan büyük olması durumunda sıfır hipotezi \%10 anlamlılık seviyesinde kabul edilmektedir (Pesaran ve Yamagata, 2008). Tablo 4'te homojenlik testi sonuçları verilmiştir;

Tablo 4: Homojenlik Testi Sonuçları

\begin{tabular}{|l|c|c|}
\hline & Test İstatisiği & $\begin{array}{c}\text { Olasılık } \\
\text { Değeri }\end{array}$ \\
\hline Delta_tilde & -0.882 & 0.811 \\
\hline Delta_tilde_adj & -1.080 & 0.860 \\
\hline \multicolumn{2}{|c|}{ Tablo 4'teki homojenlik testi } \\
sonuçlarına bakıldığında, olasılık değerleri
\end{tabular}


İzmir İktisat Dergisi (İzmir Journal of Economics) , Yıl:2019 Cilt:34 Sayı:2 ss. 265-277

0,10'dan büyük olduğu için sıfır hipotezi kabul

edilmekte, diğer bir ifadeyle sabit terim ve eğim

katsayılarının homojen olduğu sonucuna ulaşılmaktadır.

Tablo 5: Kónya (2006) Panel Bootstrap Nedensellik Testi Sonuçları (Demokratikleşmeden vergi gelirlerine doğru nedensellik analizi)

$\mathbf{H}_{0}$ : Demokratikleșme vergi gelirlerinin nedeni değildir.

\begin{tabular}{|l|c|c|c|c|}
\hline \multicolumn{2}{|c|}{} & \multicolumn{3}{c|}{ Bootstrap Kritik Değerleri } \\
\hline Ülkeler & Wald İstatistik & $\mathbf{1 \%}$ & $\mathbf{5 \%}$ & $\mathbf{1 0 \%}$ \\
\hline Avusturya & $\mathbf{1 2 1 . 8 4 6 1 6 * *}$ & 181.37213 & 50.17987 & 28.06572 \\
\hline Belçika & 0.29762691 & 114.05370 & 39.56768 & 24.27143 \\
\hline Kanada & 2.2523155 & 559.58252 & 89.72383 & 35.57854 \\
\hline Şili & 11.422867 & 192.28870 & 57.10034 & 31.20281 \\
\hline Çekya & 3.6285222 & 101.80573 & 39.84246 & 23.33228 \\
\hline Danimarka & $0.32232986 E-01$ & 111.29328 & 36.57084 & 19.85261 \\
\hline Estonya & $\mathbf{1 4 5 . 0 3 2 3 8 * *}$ & 169.03049 & 54.01373 & 31.72270 \\
\hline Finlandiya & 0.53141909 & 254.99837 & 63.29494 & 29.83981 \\
\hline Fransa & 9.8243710 & 215.65756 & 62.19837 & 33.53696 \\
\hline Almanya & 5.3264984 & 177.92693 & 46.36525 & 24.59199 \\
\hline Yunanistan & 7.0805532 & 197.16248 & 63.48968 & 35.04650 \\
\hline Macaristan & 5.0685271 & 90.57264 & 29.45114 & 17.17506 \\
\hline İzlanda & 10.826154 & 80.37459 & 29.47312 & 17.85783 \\
\hline İrlanda & 6.6995101 & 152.56178 & 56.47094 & 33.40699 \\
\hline İsrail & 12.618168 & 153.03444 & 51.35733 & 28.81676 \\
\hline İtalya & $\mathbf{2 8 . 3 1 8 3 1 8 *}$ & 147.20032 & 46.96933 & 26.77901 \\
\hline Güney Kore & $\mathbf{1 8 5 . 0 2 6 5 5 * *}$ & 237.14070 & 69.04626 & 35.81649 \\
\hline Letonya & 6.4244970 & 359.86014 & 90.44754 & 44.50959 \\
\hline Litvanya & $\mathbf{1 1 . 4 6 4 6 4 * *}$ & 327.22525 & 96.47169 & 49.35876 \\
\hline Lüksemburg & 3.1557114 & 383.25909 & 44.99257 & 22.02120 \\
\hline Meksika & 23.850975 & 359.54529 & 86.13030 & 44.59410 \\
\hline Hollanda & 1.4801983 & 366.42029 & 98.83447 & 49.27756 \\
\hline Norveç & $\mathbf{2 9 2 . 5 6 9 5 8 * *}$ & 443.43665 & 107.47900 & 51.08615 \\
\hline Polonya & $0.39932214 \mathrm{E}-02$ & 290.64639 & 80.64561 & 41.62704 \\
\hline Portekiz & 1.1093057 & 188.43069 & 49.04161 & 26.49388 \\
\hline Slovakya & 2.9104310 & 169.62569 & 42.87516 & 21.73834 \\
\hline Slovenya & 1.5315438 & 233.98409 & 67.15105 & 32.19355 \\
\hline İspanya & 3.4306898 & 246.58820 & 51.47202 & 25.79323 \\
\hline İsveç & 0.84884690 & 197.34047 & 53.22788 & 24.97893 \\
\hline Türkiye & 3.9160149 & 142.04057 & 26.95625 & 13.85239 \\
\hline İngiltere & 0.65902179 & 88.94918 & 32.51540 & 19.18879 \\
\hline Amerika & 7.2744721 & 128.22394 & 42.47474 & 24.58426 \\
\hline
\end{tabular}

Not: * $10 \%,{ }^{* *} 5 \%,{ }^{* * *} 1 \%$ seviyesinde anlamlılığı göstermektedir. Ülkelerin sıralamasında ülkelerin İngilizce isimleri esas alınmıștır.

\subsection{Kónya (2006) Panel Bootstrap Nedensellik Testi}

Kónya (2006) tarafından literatüre kazandırılan Panel Bootstrap Granger nedensellik testinin temelinde Zellner (1962) tarafından geliştirilen görünürde ilişkisiz regresyon (SUR- Seemingly Unrelated Regression) tahmincileri ile tahmin yapması yatmaktadır. Test sonucunda her bir yatay kesit için üretilen ve tahmin için kullanılan Bootstraplı kritik değerler sayesinde yatay kesit bağımlılığı varsayımı gevşetilmiş olmaktadır. Ayrıca test durağan ve 


\section{M. Ü. ŞAŞMAZ}

eșbütünleșik olmayan serilerin analizinde de yapılabilmekte bir başka ifadeyle birim kök testi ile eşbütünleşme testi uygulanmadan da Bootstrap nedensellik testi kullanılabilmektedir (Kónya, 2006: 991). SUR tahmincileri ile yatay kesit bağımlılığının olduğu durumlarda EKK tahmincilerine göre daha etkin sonuçlar alınabildiğinden Kónya (2006) Panel Bootstrap nedensellik testinin kullanılması daha güvenilir sonuçların bulunmasını sağlayacaktır.

Tablo 6: Kónya (2006) Panel Bootstrap Nedensellik Testi Sonuçları (Vergi gelirlerinden demokratikleşmeye doğru nedensellik analizi)

\begin{tabular}{|c|c|c|c|c|}
\hline \multicolumn{5}{|c|}{ Ho: Vergi gelirleri demokratikleșmenin nedeni değildir. } \\
\hline \multirow[b]{2}{*}{ Ülkeler } & \multirow[b]{2}{*}{ Wald İstatistik } & \multicolumn{3}{|c|}{ Bootstrap Kritik Değerleri } \\
\hline & & $1 \%$ & $\mathbf{5 \%}$ & $10 \%$ \\
\hline Avusturya & 1.9694435 & 117.38939 & 40.65699 & 23.36041 \\
\hline Belçika & 16.791497 & 177.54066 & 60.32927 & 34.63663 \\
\hline Kanada & $202.86661 * *$ & 389.62457 & 80.09618 & 37.82336 \\
\hline Şili & 24.610938 & 257.76337 & 78.97296 & 41.11135 \\
\hline Çekya & 150.12979** & 430.91434 & 108.69244 & 51.58201 \\
\hline Danimarka & 0.71157768 & 263.12369 & 71.64661 & 37.72795 \\
\hline Estonya & $34.966272^{*}$ & 254.47095 & 67.05206 & 32.88987 \\
\hline Finlandiya & $36.100286^{*}$ & 149.77374 & 45.04599 & 20.22374 \\
\hline Fransa & $0.91197659 \mathrm{E}-01$ & 109.68134 & 35.08395 & 18.82295 \\
\hline Almanya & 35.585467 & 246.30865 & 72.36492 & 40.82410 \\
\hline Yunanistan & 8.9734532 & 112.71308 & 40.16333 & 24.77791 \\
\hline Macaristan & 6.4807487 & 258.07202 & 76.68792 & 45.34328 \\
\hline İzlanda & 11.322899 & 283.19232 & 54.26108 & 29.48936 \\
\hline İrlanda & 10.750185 & 376.23911 & 86.96120 & 47.24387 \\
\hline İsrail & $60.358642^{*}$ & 212.43459 & 66.01227 & 38.65327 \\
\hline İtalya & 11.309639 & 143.71370 & 48.89019 & 29.81331 \\
\hline Güney Kore & 0.23244136 & 120.31218 & 37.57526 & 22.47295 \\
\hline Letonya & 0.22178845 & 110.90147 & 40.74995 & 25.45745 \\
\hline Litvanya & 4.9301050 & 211.44038 & 55.32396 & 33.61299 \\
\hline Lüksemburg & 6.1638050 & 114.67513 & 40.63541 & 27.24308 \\
\hline Meksika & 0.22540241 & 118.38704 & 37.96691 & 23.05735 \\
\hline Hollanda & 1.4452137 & 67.15900 & 25.70989 & 16.61688 \\
\hline Norveç & 0.19935823 & 127.03188 & 36.19440 & 24.26331 \\
\hline Polonya & 5.6227353 & 95.43759 & 30.28773 & 18.51581 \\
\hline Portekiz & 0.61504093 & 67.51510 & 21.78306 & 13.08626 \\
\hline Slovakya & 4.3337366 & 107.33289 & 37.32964 & 24.49213 \\
\hline Slovenya & 2.8756445 & 161.96422 & 53.62838 & 31.42735 \\
\hline İspanya & 15.968938 & 124.93616 & 49.47047 & 28.70095 \\
\hline İsveç & 7.6380748 & 191.35274 & 60.65400 & 36.41939 \\
\hline Türkiye & $0.96468026 \mathrm{E}-02$ & 35.40285 & 15.30334 & 10.37951 \\
\hline İngiltere & 6.7135969 & 58.74232 & 19.86408 & 12.55514 \\
\hline Amerika & 5.7353984 & 109.23904 & 28.50173 & 16.44710 \\
\hline
\end{tabular}

Not: $* 10 \%, * * 5 \%,{ }^{* * *} 1 \%$ seviyesinde anlamlılığı göstermektedir. Ülkelerin sıralamasında ülkelerin İngilizce isimleri esas alınmıştır. 
Kónya (2006) Panel Bootstrap nedensellik testi sonucu hesaplanan Wald istatistik değerinin Bootstrap kritik değerinden büyük olması durumunda; sıfır hipotezi "değişkenler arasında nedensellik ilişkisi yoktur" reddedilirken alternatif hipotez "değişkenler arasında nedensellik ilişkisi vardır" kabul edilmektedir.

Tablo 5'te demokratikleşmeden vergi gelirlerine doğru nedensellik testi sonuçları verilmiştir;

Demokratikleşmeden vergi gelirlerine doğru nedensellik testi sonuçlarına bakıldığında; 6 ülkede (Avusturya, İtalya, Estonya, Güney Kore, Litvanya ve Norveç) bu ilişkinin varlığı tespit edilmiştir. Diğer bir ifadeyle 6 ülkede demokratikleşmede meydana gelen bir değişmenin vergi gelirleri üzerinde değişmeye neden olacağı söylenebilir. Diğer ülkelerde demokratikleşmeden vergi gelirlerine doğru bir nedensellik ilişskisi tespit edilememiştir.

Tablo 6'da vergi gelirlerinden demokratikleşmeye doğru nedensellik testi sonuçları verilmiştir;

Vergi gelirlerinden demokratikleşmeye doğru nedensellik testi sonuçlarına bakıldığında, 5 ülkede (Kanada, Çekya, Estonya, Finlandiya ve İsrail) bu ilişkinin olduğu tespit edilmiştir. Diğer bir ifadeyle 5 ülkede vergi gelirlerinde meydana gelen bir değişmenin demokratikleşme üzerinde değişmeye neden olacağı söylenebilir. Diğer ülkelerde vergi gelirlerinden demokratikleşmeye doğru bir nedensellik ilişkisi tespit edilememiştir.

\section{SONUÇ}

Demokratikleșme olgusu, ülkelerin gelişmişlik düzeyi ile yakından ilişkili bir kavramdır. Genel itibariyle demokratikleşme seviyesi, gelişmiş ülkelerde gelişmekte olan ülkelere göre daha yüksek olduğu bilinmektedir. Nitekim ülkelerin demokratikleşme seviyeleri ile sosyal, ekonomik, siyasal ve mali düzeyleri yakın ilişki içerisindedir. Zira ülkelerin demokratikleşme seviyesi ile sosyal, ekonomik, siyasal ve mali gelişmişlik düzeyleri arasındaki ilişkiyi ortaya çıkarmak önem arz etmektedir. Buradan hareketle demokratikleşme seviyesi ile ülkelerin mali seviyelerinin belirlenmesi sürecinde önemli rolü olan vergi gelirleri arasındaki ilişki ortaya çıkarılmıştır.

Demokratikleşme ile birlikte güven ve istikrar ortamı sonucunda yatırım faaliyetleri artış göstermekte ve bunun sonucunda da milli gelir iyileşmektedir. Milli gelirde yaşanan iyileşme ile birlikte üretim ve tüketim faaliyetlerinde artışlar yaşanabilmektedir. Üretim ve tüketim faaliyetlerinin artması sonucunda devletin en önemli kaynağı olan vergi gelirlerinde de değişiklikler meydana gelmektedir. Ayrıca ekonomi politikalarında siyasi rejim ve kurumların etkili olmasına bağı olarak vergi politikaları da bu kurumlar sonucunda belirlenmektedir.

Bu çalışmada 2010-2017 döneminde 32 OECD ülkesinde demokratikleșme ve vergi gelirleri arasındaki ilişki bootstrap panel nedensellik analizi yöntemi ile araştırılmıştır. Nedensellik testi sonucuna göre 32 ülkenin 6'sinda (Avusturya, Estonya, İtalya, Güney Kore, Litvanya, Norveç) demokratikleșmeden vergi gelirlerine doğru, 5 ülkede (Çekya, Estonya, Finlandiya, İsrail, Kanada) vergi gelirlerinden demokratikleşmeye doğru nedensellik ilişkisi tespit edilmiştir. Ayrıca Estonya'da çift yönlü nedensellik ilişkisi olduğu belirlenmiştir.

Çalışma sonucunda demokratikleşme seviyesi ile vergi gelirleri arasinda nedensellik ilişkisinin ülkelerde farklılık gösterdiği görülmektedir. Bunun nedeni olarak ülkelerin içerisinde bulunduğu farklı sosyo-ekonomik ve kurumsal durumlardan kaynaklandığı söylenebilir. Nitekim ülkelerdeki vergi bilinci, hukuki alt yapı, denetim ve müeyyideler gibi demokratikleşme seviyesini etkileyen iç dinamikler her bir ülke için farklılık gösterebilmektedir. Diğer yandan, çalışma kapsamında olan ülkelerde demokratikleşme seviyeleri ile vergi gelirlerinin GSYH'ye oranı benzerlik göstermemektedir. $\mathrm{Bu}$ sonuçtan hareketle çalışmanın önemli sonuçlarından birisi, demokratikleşme seviyesi ile vergi gelirleri arasındaki ilişkinin ülkeye özgü 
faktörlerden etkilendiği ve dolayısıyla ülkeden ülkeye farklılık gösterdiğidir. Çalışmanın en önemli kısıtı verilerin ulaşılabilmesine bağlı olarak zaman kısıtıdır. Ancak örneklem sayısının yüksek olması sonuçların anlamlılığını arttırmaktadır. Bu bağlamda bu çalışmanın ileride benzer konularda araștırmalara önemli bir kaynak olabileceği düşünülmektedir.

Ülkelerde kamunun en önemli gelir kaynağını vergiler oluşturmaktadır. Ülkelerin kamu harcamalarının finansmanını sağlamak amacıyla topladığı vergiler özellikle ekonomik faaliyetlerinin yapılabilmesi açısından önem arz etmektedir. Ayrıca vergi gelirleri ülkelerin önemli ekonomi politikalarından birini oluşturmaktadır. Bu nedenle ülkelerin belli bir demokrasi eșiğini aşmasıyla vergi gelirlerini olumlu etkilemesi beklenen demokratikleșme seviyesini arttırmaya yönelik girişimlerde bulunmalarının faydalı olabileceği ifade edilebilir.

\section{KAYNAKÇA}

Acemoglu, D., ve Robinson, J. A. (2000). Democratization or repression?European Economic Review, 44(4), 683-693.

Acemoglu, D., ve Robinson, J. A. (2005). Economic origins of dictatorship and democracy. Cambridge University Press.

Alakbarov, N., ve Bayar, Y. (2018). Democratization and Economic Growth in Emerging Market Economies, Maliye Finans Yazllarl, 109, 165-180.

Andersson, P. F. (2018). Democracy, urbanization, and tax revenue, Studies in Comparative International Development, 53(1), 111-150.

Balamatsias, P. (2016). Democracy and Taxation, MPRA Paper, No. 82563, https://mpra.ub.uni-muenchen.de/82563/, (25.11.2018)

Baltagi, B. H. ve Q. Feng \& C. Kao (2012). A Lagrange Multiplier Test for Cross-sectional Dependence in a Fixed Effects Panel Data Model, Journal of Econometrics, 170(1), 164177.

Baskaran, T. (2014). Taxation and democratization, World Development, 56, 287 301.

Bates, Robert H., ve Lien, Da-hsiang Donald. 1985. "A Note on Taxation, Development, and Representative Government." Politics and Society, (14), 53-70.
Breusch, T. S. ve A. R. Pagan (1980). The Lagrange Multiplier Test and İts Applications to Model Specification in Econometrics, The Review of Economic Studies, 47(1), 239-253.

Cheibub, J. A. (1998). Political regimes and the extractive capacity of governments: Taxation in democracies and dictatorships, World Politics, 50(3), 349-376.

Ehrhart, H. (2009). Assessing the relationship between Democracy and Domestic taxes in developing countries, CERDI, Etudes et Documents, E.30. HAL Id: halshs-00553607, https://halshs.archives-ouvertes.fr/halshs00553607, (25.11.2018).

EIU (2018). Democracy Index 2017 Free speech under attack. A report by The Economist Intelligence https://pages.eiu.com/rs/753-RIQ438/images/Democracy_Index_2017.pdf, (10.1.2019).

Kenny, L. W., ve Winer, S. L. (2006). Tax systems in the world: An empirical investigation into the importance of tax bases, administration costs, scale and political regime.International Tax and Public Finance, 13(2 -3), 181-215.

Kılıçer, E., Ay, F. C., ve Ataer, S. (2016). Katalaksi Kavrami Çerçevesinde Vergileme Demokrasi Iliskisi: Türkiye-OECD Karsilastirmali Analizi/The Relationship Between Taxation and Democracy in the Frame of Catallaxy: A Comparative Analyses on 
İzmir İktisat Dergisi (İzmir Journal of Economics) , Yll:2019 Cilt:34 Sayı:2 ss. 265-277

Turkey-OECD, Finans Politik \& Ekonomik Yorumlar, 53(612), 35.

Kónya, L. (2006). Exports and Growth: Granger Causality Analysis on OECD Countries With a Panel Data Approach, Economic Modelling, 23(6), 978-992.

Meltzer, A. H. ve Richard, S. F. (1981). A Rational Theory of the Size of Government, Journal of Political Economy, 89(5), 914-927.

Mutascu, M. (2011). Taxation and democracy, Journal of Economic Policy Reform, 14(4), 343-348.

OECD (2019). Tax revenue (indicator). Total $\%$ of GDP 2000-2017. doi: 10.1787/d98b8cf5en. $\quad$ https://data.oecd.org/tax/taxrevenue.htm, (10.1.2019).

Özmen, İ. (2016). Vergi Gelirlerinin Belirleyicileri Üzerine Karşılaştırmalı Bir Analiz: BRIC-T, Sosyal Ekonomik Araștırmalar Dergisi, 16(32), 232-252.

Pesaran, M. H. (2004). General Diagnostic Tests for Cross Section Dependence in Panels, CESifo Working Paper Series, 1229.

Pesaran, M. H. ve A. Ullah \& T. Yamagata (2008). A Bias-Adjusted LM Test of Error CrossSection İndependence, The Econometrics Journal, 11(1), 105-127.

Pesaran, M. H. ve T. Yamagata. (2008). Testing Slope Homogeneity in Large Panels, Journal of Econometrics, 142(1), 50-93.

Pommerehne, W. W. ve Weck-Hannemann, H. (1996). Tax rates, tax administration an dincome tax evasion in Switzerland, Public Choice, 88(1-2), 161-170.

Profeta, P., Puglisi, R., ve Scabrosetti, S. (2013). Does democracy affect taxation and government spending? Evidence from developing countries, Journal of ComparativeEconomics, 41(3), 684-718.

Şahin, M. ve Hatırlı, S. A. (2016). Türkiye'de Vergi Uygulamaları ve Vergi Ahlakı İlişkisi:
Trabzon, Giresun ve Gümüşhane İlleri Örneği, Gümüshane University Electronic Journal of the Institute of Social Science/Gümüshane Üniversitesi Sosyal Bilimler Enstitüsü Elektronik Dergisi, 7(18), 253-272.

Tekin, A., Güney, T., ve Sağdıç, E. N. (2018). Ekonomik Özgürlüğün Vergi Kaçakçllı̆ı ve Sosyal Refah Üzerine Etkisi, Yönetim ve Ekonomi: Celal Bayar Üniversitesi İktisadi ve İdari Bilimler Fakültesi Dergisi, 25(1), 1-13.

Torgler, B. (2005). Tax morale and direct democracy, European Journal of Political Economy, 21(2), 525-531.

Türedi, S. ve Topal, M. H. (2016). Vergilendirme ve Demokrasi Arasındaki İlişki: Gelişmekte Olan Ülkeler İçin Panel Nedensellik Analizi, Eskișehir Osmangazi Üniversitesi İIBF Dergisi, Nisan, 11(1), 63-86.

United Nations (2019). Human Development Data

(1990-2017), http://hdr.undp.org/en/data, (30.1.2019).

Zellner, A. (1962). An Efficient Method of Estimating Seemingly Unrelated Regressions and Tests for Aggregation Bias, Journal of the American statistical Association, 57(298), 348368.

Zenginobuz, Ü., Adaman, F., Goksen, F., Savci, C., ve Tokgoz, M. E. (2010). Vergi, Temsiliyet ve Demokrasi İlişkisi Üzerine Türkiye'de Vatandaşların Algıları, Açık Toplum Enstitüsü Türkiye Temsilciliği ve Boğaziçi Üniversitesi Araştırma Fonu Ortak Araştırması, ISS/EC 2010-03

Ziari, R. ve Rahemi, H. (2013). The relationship between democracy and revenue of budget, International Journal of Management Sciencesand Business Research, ISSN (22268235) Vol-2, Issue 7, 17-21. http://www.ijmsbr.com/Vol\%202,\%20Issue \%207\%20paper\%20(2).pdf, (25.11. 2018). 